\title{
The Culture and Tourism in the City of Prizren (Socio-Cultural Psychological and Antopological Reflection)
}

\author{
Mr. Sc. Batjar Halili \\ University of Prizren \\ Doi: 10.5901/mjss.2013.v4n4p205 \\ Email: psikologuklinik@hotmail.com
}

\begin{abstract}
I would like to bring in this study the culture and the historical development of the city of Prizren with its inner values considered as one of the most qualified cities for the culture, tourism and legacy apart from other community centers. These community centers have lost from their legacy because they haven't developed their cultural potential and in other cases thay haven't the natural historical resources that influence in making a special program for attracting the tourists. The development of the legacy is a process and the community has to pass though three steps described below as the part of this session. A powerful program of legacy requires investment and engagement of both resources; the financial and the human resources under a potent leadership.
\end{abstract}

\section{Introduction}

The word "culture" in the daily life implicates numerous aspects of life. For the most of psychologists, sociologists and antropologists the term of culture involves learned behaviors, believes, viewpoints, values and ideals that are caracteristics of a certain society or population.

\section{The Socio-Cultural Reflection}

The word "culture" comes from the latin language with the meaning "development, project", the complex of the achievements of a certain population and of the whole humankind in the social, intellectual and generation area. In other words it includes the range of development that a nation or a certain social group or a person has achieved in a certain area of cultural artistic activity. (Ndreca 2000)

Due to the cultural infrastructure that works on protection, development and presentation of values of legacy in material anf spiritual ways, the Prizren city plans its opportunities counting on the development of tourism as a profitable economic activity. Prizren has an enviable potential of cultural values inherited from different historical epochs becoming thus, as one of the most attended touristic centers with 24 identified archeological locations, 39 idols from christian religion as well as 46 idols from islam religion and up to 74 other objects with evident characteristics of ethnical architecture.

The Castle built up to the hill of the city, the Church of Saint Friday (Shën Premtes), The Monasteryof Head of Angels (Kryengjëjve), The Church of Saint Savior (Shën Shpëtimtarit), the Kathedral of Auxiliary Dona (Zonjës Ndihmëtare), the Mosque of Sinan Pasha, the Hammam of Gazi Mehmet Pasha, The Old Bridge of Stoun, all these are just a part of the material legacy that come across of the beautiful city of Prizren.

Within a short period of time tourism has brought a close connection between different people, regional cultures, races and religions.

Prizren is known also for the good tradition of fine arts. This tradition consists on organizing a continuity numerous cultural manifestations such as, the festival of the long-standing civic song named "The Lily of Prizren", the festival of the short film "Dokufest" as a good initiative ofthe Theater of Profesionists of the city, "The Feast of Grape"s Harvest" as well as a variety of other cultural events in national and international level that make Prizren more attractive in the touristic perspective.

So, the social and cultural aspects can enrich the perspective of tourism and provide opportunities for the arts, the image, the food, the literature, the language, the religion and the history. From the other hand the tourists themselves bring their socio-cultural attributes that can influencein both ways, the positive and negative one, depending on how the expectant place has organizied the tourism (Gorica 2007). 


\section{The Psychological Reflection}

The image of a place is an important component of tourism because it influences the behavior of the tourists, the encouragement of numerous activities and creative experiences.

The studies has shown that image is the destination that influences in forming the process of reflection and the positive feelings of travellers.

The image that the beautiful city of Prizren offers in the historical, archeological, cultural, religious and social context are the elements that inspire the tourists with the beautiful and pleasant feelings while they choose to have a comfortable relaxationin a place that can be a model of creativity.

The city of Prizren is well-known from the antiquity as a unique place in Balcan for the values of its legacy, for the different civilizations and religions. Due to the favourably geographic position, harmonic interlacing of these cultures in the course of history and an enviable number of monuments of all epochs, the city of Prizren with the significant epithet as " the museum city" and "the museum under the open sky" is considered as the most beautiful citiy of the republic of Kosovo. Placed in the feet of mountains of Sharri (that are declared as "the national park") between the two riverside of Lumbardhi and in the crossing of the important trade roadways among of west and east, the city of Prizren has been wellknown as an important cultural, economic and diplomatic center. ${ }^{1}$

Kurt Levin, a german psychologist explain "his concept about the wideness of life which is the area where an individual proceeds". According to Levin the area of life includes:

$>$ The Individual;

$>$ The People around the individual

$>$ The Objects that are perceived from him

$>$ The Ideas

Thus, according to the definition of Levin, Prizren constitutes the wideness where the individual proceeds. Every tourist who comes in the city of Prizren becomes astonished with the individuals of this city, with the people around who come from different cultures with a stable multi-ethnic cohabitation and with the historical, cultural and archeological monuments that are all around making this city a real pearl of Albanian beauty, and that we can freely consider it as the widerness of life where the tourists proceed and are pleased.

Guyer-Freuler gives a psychological definition for tourism where it says: "Tourism is the phenomena of our epoch, aftermath of a need in growth for satisfaction, relaxation, progress of a feeling of beauty for the nature, development of the contacts among of different people that follows with a growth of trade, industry and development of the means of transport"(Bakiu 2007).

All these elements mentioned above include also the social role of the tourists, the artistic motivation, the contacts among of tourists and the members of the expectant society as well as the environmental definitions for tourist behaviors. (Pearce, 1982).

\section{Anthropological Reflection}

The american anthropologist Leslie A. White,1900-1975 emphasizes that the human behavior flow down from using the symbols. The Arts, religion, money, historic institutions relate with using of symbols" (Memushi 2000).

The cultural capacity of the city of Prizren gives the tourists that attend this city the opportunity to comprehend the cultural level based on a learned symbolic system.

Through symbols the people can learn how to develop certain meanings and to communicate them to others with effectiveness.

The cultural components of the city of Prizren have been served also as a motivation in social innovations therefore we can confirm that the culture of Prizren is an integrated culture. The integration of economical, political and social aspects of the culture occures as the cause of the touristic component of this city, which is known in the social psychology as the influence of social factors in behaviors, believes, attitudes within and among of social groups.

\section{Conclusions}

In conclusion the factor culture in the city of Prizren is multi-dimensional. Knowing the fact that the culture itself is a part of the social life, its components such as, the cultural identity, the cultural wideness, the geographical dimensions,

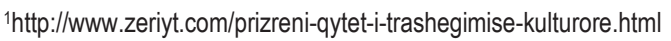


historical dimensions as well as educative dimensions are components that influence direcly in touristic development of Prizren. The city of Prizren is built up in an area where two cultures and three major religions are met in the course of history, marking and testifying events and personalities of ancient epochs. Monuments such as, The Castle of Prizren, The Church of Saint Friday, The Mosque of Sinan Pasha, The Hammam of Gazi Mehmet Pasha, etc, present the legacy with a special historical value for the city of Prizren as well as for the whole Republic of Kosovo.

Besides these monuments there is another cultural inheritance conserved from the citiziens of Prizren. This is reflected through the diversity keeped succesfully till present days into tradition, religion, population making proud the citiziens of Prizren.

\section{References}

Mikel Ndreca (2000), The Dictionary of foreign words and expression, Prishtinë.

Luan Memushi (2000), Antropology, Libri Universitar, Tiranë.

Klodiana Gorica and Fioralba Vela (2007), The Strategy of Tourism, "Pegi" Tiranë.

Vjollca Bakiu (2004), Management of Tourism, ERIK, Tiranë.

Petri Hottola, (2004) Culture confusion, Intercultural Adaptation in Tourism, Finland.

http://www.zeriyt.com/prizreni-qytet-i-trashegimise-kulturore.html

Perussia, F. (1989). An introduction to the social psychology of tourism. Paper presented in the international conference: "Turismo e ambiente nella società post-industriale", Milano: Fast-Tci, 1989. 
